\title{
Concentration, Spatial Distribution and Potential Ecological Risk of Heavy Metals in Stream Sediments of the Misiones Province, Argentina
}

\author{
Dongjie Zhao ${ }^{1,2}$, Yuming Chen ${ }^{1, *}$, Weibo Zhang ${ }^{1}$, Xifeng Chen ${ }^{1} \mathbb{D}$, Xiufa Chen ${ }^{1}$ and Fuliang Zhang ${ }^{1}$ \\ 1 Development and Research Center of China Geological Survey, Beijing 100037, China; \\ geozhaodj@163.com (D.Z.); zhangwb2007@163.com (W.Z.); chen6100117@126.com (X.C.); \\ cxiufa@mail.cgs.gov.cn (X.C.); ZFL7288@163.com (F.Z.) \\ 2 School of Earth Sciences and Resources, China University of Geosciences, Beijing 100083, China \\ * Correspondence: cyuming@mail.cgs.gov.cn
}

Citation: Zhao, D.; Chen, Y.; Zhang, W.; Chen, X.; Chen, X.; Zhang, F. Concentration, Spatial Distribution and Potential Ecological Risk of Heavy Metals in Stream Sediments of the Misiones Province, Argentina. Minerals 2021, 11, 1112. https://doi.org/10.3390/min11101112

Academic Editor: Pedro Tume

Received: 22 September 2021

Accepted: 8 October 2021

Published: 11 October 2021

Publisher's Note: MDPI stays neutral with regard to jurisdictional claims in published maps and institutional affiliations.

Copyright: (c) 2021 by the authors. Licensee MDPI, Basel, Switzerland. This article is an open access article distributed under the terms and conditions of the Creative Commons Attribution (CC BY) license (https:// creativecommons.org/licenses/by/ $4.0 /)$.

\begin{abstract}
One hundred and twenty-eight stream sediment samples were collected in the Misiones province of Argentina by the low-density geochemical mapping project of the China Geological Survey. The analyzed data were used to study the concentration, spatial distribution, local pollution level and potential ecological risk of eight heavy metals ( $\mathrm{As}, \mathrm{Cd}, \mathrm{Cr}, \mathrm{Cu}, \mathrm{Hg}, \mathrm{Ni}, \mathrm{Pb}$ and $\mathrm{Zn}$ ) by factor analysis, geoaccumulation index $\left(I_{g e o}\right)$, enrichment factor $(\mathrm{EF})$ and the Hakanson's potential ecological risk index $\left(E_{r}^{i}\right.$ and $\left.R I\right)$ methods. Results showed that the background values (median) of those elements were 2.97 ppm, 0.13 ppm, 212.60 ppm, 322.53 ppm, 0.013 ppm, 64.42 ppm, 12.58 ppm, and 198.85 ppm, respectively. Except for $\mathrm{Hg}$, the contents of other elements were higher than the abundance of continental crust. The spatial distribution of $\mathrm{Cu}$ and $\mathrm{Zn}$ in stream sediments were consistent, while that of other elements were different. The factor analysis results implied that $\mathrm{Cd}, \mathrm{Cr}$, $\mathrm{Cu}, \mathrm{Ni}$ and $\mathrm{Zn}$ were mainly affected by geological background and inherited the characteristics of regional parent rocks. Furthermore, $\mathrm{Pb}$ was not only controlled by natural conditions but also related to human activities, while As and $\mathrm{Hg}$ represented the anthropogenic sources, and their concentrations were affected by human activities. The results of $I_{\text {geo }}$ and EF told us that $\mathrm{Cu}$ was heavily polluted in stream sediments; $\mathrm{Pb}$ and $\mathrm{Zn}$ were largely mildly polluted; $\mathrm{As}, \mathrm{Cr}, \mathrm{Cd}, \mathrm{Ni}$ and $\mathrm{Hg}$ were mostly nonpolluted. The ecological risks were ordered as $\mathrm{As}>\mathrm{Cu}>\mathrm{Cd}>\mathrm{Pb}>\mathrm{Hg}>\mathrm{Cr}>\mathrm{Ni}>\mathrm{Zn}$. In general, the potential ecological risk of heavy metals in the Misiones province was low, but As and $\mathrm{Cu}$ also have a high ecological risk at some sampling points, which should be considered.
\end{abstract}

Keywords: heavy metals; stream sediments; concentration; ecological risk; Misiones province

\section{Introduction}

Stream sediments are an essential destination and central storage place of heavy metals in water and potential pollution receptors and sources [1]. Modern human activities have brought many harmful heavy metals, radionuclides and organic pesticides into rivers. They are adsorbed by suspended solids, settled along with them, and finally enriched in stream sediments [2]. The content of pollutants in sediments are several times higher than that in water, even up to several orders of magnitude. However, sediments can release heavy metals into the water when environmental conditions change, causing secondary pollution. Therefore, stream sediments have become a vital enrichment site for pollutants in the earth surface system and can reflect the geochemical characteristics of the river basin [3]. The geochemical information on stream sediments is widely used in large-scale geochemical mapping and plays an essential role in investigating the regional environmental background and evaluating environmental pollution [4-7]. In China, the $\mathrm{Cu}$ geochemical map was drawn based on the analysis results of millions of stream sediments across the country, revealing the distribution of $\mathrm{Cu}$ at the national scale [8]. 
Heavy metals are typical cumulative pollutants with the characteristics of nondegradability, significant biotoxicity and persistence $[9,10]$. After heavy metals enter the water environment, they usually combine with $\mathrm{Fe}$, Mn oxides, sulfides, organics and clay minerals in the sediments and quickly settle into the sediments. Then, they will be enriched in plants or other objects to varying degrees and eventually cause potential risks to human health through the food chain [11]. In addition, anthropogenic heavy metals in sediments have higher mobility, bioavailability and biotoxicity [12]. Therefore, environmental pollution and ecological risks of heavy metals have attracted more and more attention. Local environmental and human-health protection requires the ascertainment of heavy metals concentration, distribution characteristics, and pollution status in sediments.

Although the tropical forest region is rich in agriculture, forestry, water resources, and tourism, its environmental carrying capacity is weak and it is a relatively fragile ecological environment [13]. The Misiones province has a typical subtropical rainforest climate located in the northeast of Argentina, across the Misiones Plateau. The landform is mainly mountainous, with a highest elevation of $843 \mathrm{~m}$. This area is famous for its abundant natural vegetation, with more than $80 \%$ forest coverage. The economy of the study area is dominated by agriculture and tourism, known for its rich mate tea, followed by forest products, soybeans, tobacco and fruits. The Iguazu Falls on the northern border is a world-famous tourist attraction. The Cretaceous basalts cover almost the entire Misiones province [14], some of which have undergone weathering to form widely distributed laterite layers on the surface [15]. Previous studies on heavy metals in soils of Argentina have generally focused on Pampas Estepa [16-18], with few studies on this area and few geological and environmental investigations carried out in the past. Boglione et al. [19] studied the adsorption kinetics of As on the lateritic soil from Misiones province and believed that the laterites have a good adsorption capacity for As. Therefore, relevant regional environmental assessment data are relatively scarce, and there is no unified understanding of the geochemical background and distribution of heavy metals in this region. Agriculture and tourism, which account for most of the economy of the Misiones province, are closely related to environmental protection. Only by knowing the concentration of heavy metals can we achieve real-time understanding and monitoring of the pollution status and level in this area and provide a better basis and reference for agricultural production and tourism development. So, it is necessary for local government to obtain information on the concentrations, distribution characteristics and sources of heavy metals.

In cooperation with Argentina's Geological and Mineral Survey, the Development and Research Center of China Geological Survey carried out low-density geochemical mapping in the Misiones province, Argentina, in 2019 and obtained high-quality geochemical data of 71 elements and oxides. The purpose of this work is to carry out a multiobjective geochemical survey in the Misiones province with a view to providing basic data and information for agricultural, environmental and mineral resource studies. Based on that data, this paper aimed to give the geochemical background and spatial distribution characteristics of eight heavy metals ( $\mathrm{As}, \mathrm{Cd}, \mathrm{Cr}, \mathrm{Cu}, \mathrm{Hg}, \mathrm{Ni}, \mathrm{Pb}$ and $\mathrm{Zn}$ ) in stream sediments of the Misiones province, discuss the sources of these elements and evaluate their contamination status and potential ecological risk. This study also aims to provide the scientific basis for the environmental investigation and pollution prevention of heavy metals in the study area.

\section{Materials and Methods}

\subsection{Sampling}

Sampling grids were divided according to $15^{\prime}$ of longitude and $10^{\prime}$ of latitude when designing. One sample was collected from the relatively low-lying places of each grid to ensure that sampling points were evenly distributed as much as possible. A total of 128 samples were collected in the Misiones province (Figure 1), with a sampling depth of 5-20 cm. Duplicate samples were distributed at the same site but at different locations (at least $2 \mathrm{~m}$ apart), and their quantity was seven (5\% of the total samples). Three subsamples of equilateral triangles with a distance of $50 \mathrm{~m}$ were collected at each sampling site for 
combination. Each combination sample weighed about $500 \mathrm{~g}$, half of which were brought back to China for analysis. The remaining half was left in Argentina. In order to be consistent with the soil environmental-assessment standard stipulated by the International Soil Society, the particle size of samples collected in the field should be less than $2 \mathrm{~mm}$. Moreover, the sampling medium should mainly be stream sediment, supplemented by fine-grained soil in the low-lying area. The soils at each sampling site were all formed by natural deposition and not modified by human activities later, and there was no obvious pollution source near the sampling sites.

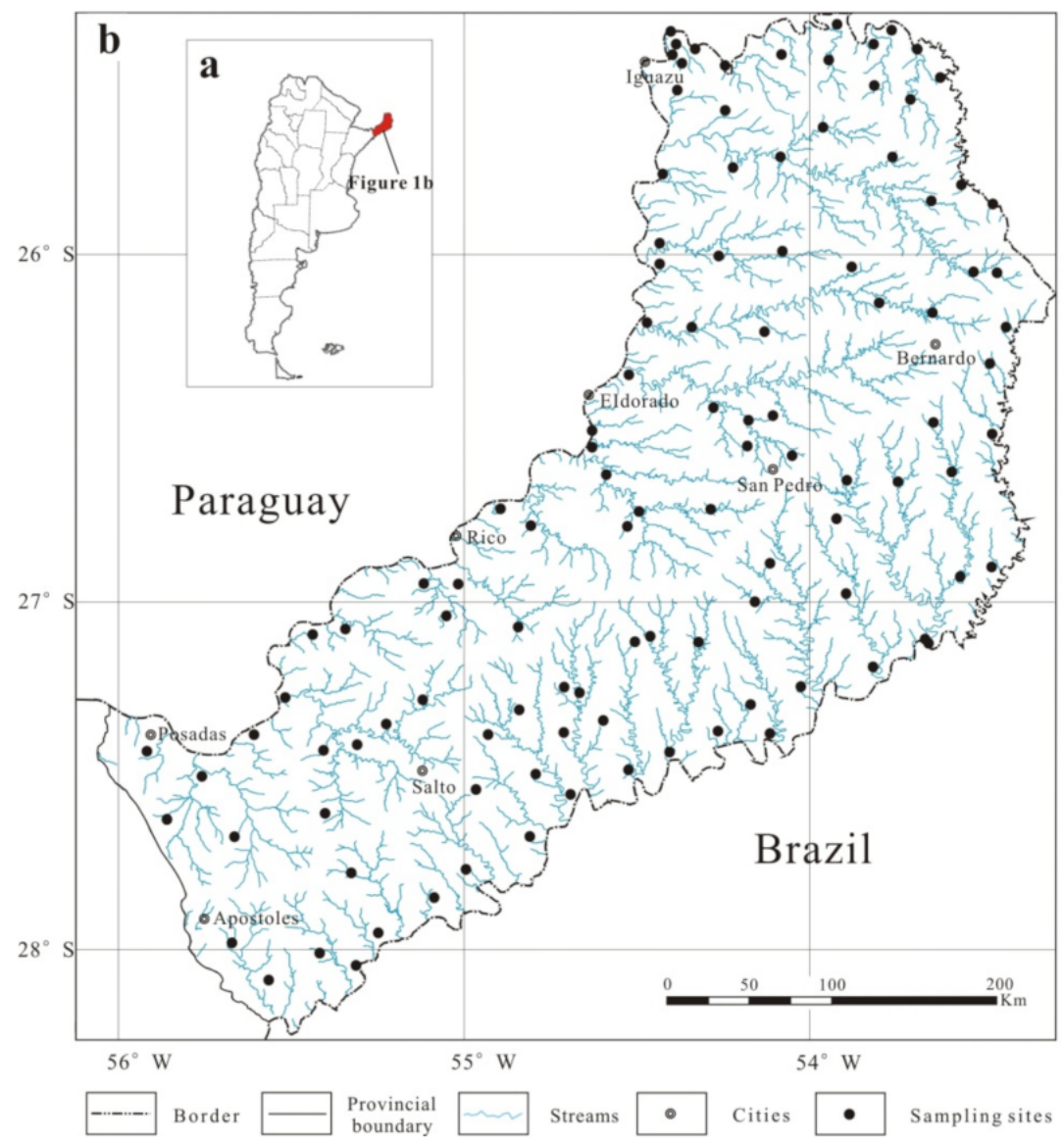

Figure 1. Sampling sites of stream sediments in the Misiones province, Argentina. (a): administrative map of Argentina; (b): the Misciones province.

\subsection{Sample Processing and Analysis}

The stream sediment samples were dried indoors and stored in nonpolluting polyethene plastic bottles. They were prepared before sending to laboratory for analysis. The procedures were as follows: drying (not directly under the sun) - crushing (to prevent the grains clustering into lumps) - sieving (discarding the portion over or lower the $\times$ mesh) grinding (grind samples to 200 mesh in agate or a pure-aluminum-porcelain mill) splitting and weighing (depending on the requirement of analysis) - bottling (polypropylene or plastic bottle) - storing (store the rest of samples in storage room) [20-22]. The sample pretreatment method was as follows: $0.25 \mathrm{~g}$ sample was dissolved by $\mathrm{HF}+\mathrm{HNO}_{3}+$ $\mathrm{HClO}_{4}+$ aqua regia, then add $25 \mathrm{~mL}$ solution in $5 \%$ aqua regia, pipette $1 \mathrm{~mL}$ clear solution, and then dilute to $10 \mathrm{~mL}$ with $2 \% \mathrm{HNO}_{3}$ [23]. The samples were analyzed in the laboratory of the Institute of Geophysical and Geochemical Exploration (IGGE), Chinese Academy of Geological Sciences. In order to ensure the reliability and consistency of geochemical data, strict quality control measures have been taken to ensure that the whole testing process is carried out in a steady state at all times. Certificate samples were used, and the accuracy of 
analyses was better than $10 \%$ for trace elements. Duplicate samples with random sampling at $5 \%$ of the total number of samples in secret code were analyzed, and the relative errors of repeated sample analyses were less than $10 \%$. The quality control results of the sample analysis are shown in Table 1.

Table 1. Analytical methods and quality control.

\begin{tabular}{|c|c|c|c|c|c|c|c|}
\hline \multirow[b]{2}{*}{ Parameters } & \multirow[b]{2}{*}{ Sample Preparation } & \multirow[b]{2}{*}{ Analytical Method } & \multirow{2}{*}{$\begin{array}{l}\text { Detection Limit } \\
\quad(\mathrm{ppm})\end{array}$} & \multirow[b]{2}{*}{$\begin{array}{c}\text { Reportable } \\
\text { Rate (\%) }\end{array}$} & \multicolumn{3}{|c|}{ Passing Rates (\%) } \\
\hline & & & & & SRMs & $\begin{array}{l}\text { Laboratory } \\
\text { Replicates }\end{array}$ & $\begin{array}{c}\text { Field } \\
\text { Duplicate }\end{array}$ \\
\hline As & Aqua regia & HG-AFS & 0.1 & 99.7 & 99.8 & 98.5 & 94.9 \\
\hline $\mathrm{Cd}$ & Acid digestion & ICP-MS & 0.01 & 99.9 & 99.7 & 100 & 95.3 \\
\hline $\mathrm{Cr}$ & Powder pellet & XRF & 0.5 & 99.8 & 99.7 & 98.6 & 95.8 \\
\hline $\mathrm{Cu}$ & Acid digestion & ICP-MS & 1 & 100 & 100 & 99.7 & 98.1 \\
\hline $\mathrm{Hg}$ & Aqua regia & CV-AFS & 0.0005 & 100 & 99 & 96.2 & 88.8 \\
\hline $\mathrm{Ni}$ & Acid digestion & ICP-MS & 0.5 & 99.9 & 100 & 99.7 & 97.7 \\
\hline $\mathrm{Pb}$ & Acid digestion & ICP-MS & 1 & 100 & 100 & 99.9 & 99.5 \\
\hline $\mathrm{Zn}$ & Acid digestion & ICP-MS & 2 & 100 & 99.8 & 100 & 98.1 \\
\hline
\end{tabular}

Notation: Acid digestion: $\mathrm{HF}, \mathrm{HNO}_{3}, \mathrm{HClO}_{4}$, aqua regia; CV-AFS: Cold Vapor Atomic Fluorescence Spectroscopy (IGGE, Langfang, China); HG-AFS: Atomic Fluorescence Spectrometry (IGGE, Langfang, China); ICP-MS: Inductively Coupled Plasma Mass Spectrometry (IGGE, Langfang, China); XRF: X-Ray Fluorescence Spectrometry (IGGE, Langfang, China); SRM: Standard Reference Material; Laboratory Replicates: Laboratory replicate analysis; Field Duplicates: Field Duplicate samples.

\subsection{Evaluation Method}

\subsubsection{Geoaccumulation Index $\left(I_{g e o}\right)$}

The $I_{g e o}$ is used to assess the level of heavy-metal contamination of river, estuarine and marine sediments by comparison with the background level of natural fluctuations [24]. The mathematical equation that represents this index is as follows:

$$
I_{\text {geo }}=\log _{2}\left[C_{i} /\left(1.5 \times B_{i}\right)\right]
$$

where $C_{i}$ is the metal concentration determined, 1.5 represents the attenuation factor to account for lithogenic variations in background concentrations at the site, and $B_{i}$ is the background concentration of the corresponding element. Results obtained are classified to give us an understanding of the pollution status of the site.

Contamination assessment of stream sediments depends on the accurate determination of the background values. To assess the degree of contamination and evaluate the adequate background for determining anthropogenic contamination in $\mathrm{Cd}, \mathrm{Cr}, \mathrm{Cu}, \mathrm{Ni}, \mathrm{Pb}$ and $\mathrm{Zn}$ in bed sediments of the Pampean area river basin, Castro et al. [25] calculated the $I_{\text {geo }}$ values using selected lithogenic backgrounds (loess, loessial sediments and paleosoils), the metal concentrations of riverbed sediments in the residual fraction and the global average shale (ASTW) [26]. Magni et al. [27] used the ASTW to evaluate the anthropogenic contamination of $\mathrm{Cd}, \mathrm{Cr}, \mathrm{Cu}, \mathrm{Ni}, \mathrm{Pb}$ and $\mathrm{Zn}$ in riverbed sediments of the Pampean area of Argentina. In this study, the global average basalt [26] was used as $B_{i}$ to calculate the $I_{g e o} s$. According to the results, the pollution degree is divided into seven levels corresponding to different contamination grades (Table 2).

Table 2. The $I_{\text {geo }}$ and contamination grades of heavy metals.

\begin{tabular}{ccc}
\hline $\boldsymbol{I}_{\text {geo }}$ & Class & Contamination Grades \\
\hline$<0$ & 1 & uncontaminated \\
$0-1$ & 2 & mild contamination \\
$1-2$ & 3 & moderately contaminated \\
$2-3$ & 4 & moderate to heavily contaminated \\
$3-4$ & 5 & heavily contaminated \\
$4-5$ & 6 & heavily to extremely contaminated \\
$5-6$ & 7 & extremely contaminated \\
\hline
\end{tabular}




\subsubsection{Enrichment Factor (EF)}

Enrichment factor is an essential index for quantitative evaluation of sediment pollution level [28-30], and the mathematical equation is as follows:

$$
\mathrm{EF}=\left(C_{i} / C_{n}\right)_{\text {sample }} /\left(C_{\mathrm{i}} / C_{\mathrm{n}}\right)_{\text {background }}
$$

where $C_{i}$ is the metal concentration, $C_{n}$ is the concentration of the reference element, and the global average basalt [26] was used as the concentrations in the selected background.

The classification rules of enrichment factors on heavy-metal pollution levels of sediments are listed in Table 3. In this case, a reference element refers to a geochemically stable one, characterized by the absence of vertical mobility and degradation phenomena during weathering and soil formation, and includes elements such as Al, Ti, Fe and Sc [31,32]. The Sc concentration in stream sediments of the study area was relatively stable (3.29-49.18), with an average of 28.21 , close to the Sc content (30) in the global average basalt. Therefore, Sc was selected as the reference element in this study.

Table 3. The enrichment factors and pollution level.

\begin{tabular}{ccc}
\hline EF & Degree of Enrichment & Pollution Level \\
\hline$<2$ & no or minor & uncontaminated \\
$2-5$ & moderate & moderately contaminated \\
$5-20$ & signifcant & moderately severe contaminated \\
$20-40$ & very high & extremely severe contaminated \\
\hline 40 & extremely high & extred \\
\hline
\end{tabular}

\subsubsection{Potential Ecological Risk Index (PERI)}

An ecological risk assessment was conducted using the method developed by Hakanson [33] to evaluate the potential effect of heavy metals in stream sediments. The assessment combined the concentrations of heavy metals, ecological effects, environmental effects, and toxicity coefficients, which could reflect the pollution level of pollutants in the sediments and reveal the potential ecological risk of pollutants [34]. The mathematical equation is as follows:

$$
R I=\sum_{i}^{m} E_{r}^{i}=\sum_{i}^{m} T_{r}^{i} \times C_{r}^{i}=\sum_{i}^{m} T_{r}^{i} \times \frac{C^{i}}{C_{n}^{i}}
$$

where $R I$ is the comprehensive potential ecological risk index of heavy metals; $E_{r}^{i}$ is the potential ecological risk coefficient of a single heavy metal; $C_{r}^{i}$ is the pollution index; $C^{i}$ is the concentration of heavy metals; $C_{n}^{i}$ is the concentration of reference elements selected from the average globe blast; $T_{r}^{i}$ is the toxicity coefficient of metals, and the coefficients for each metal are $\mathrm{As}=10, \mathrm{Cd}=30, \mathrm{Cr}=2, \mathrm{Cu}=5, \mathrm{Hg}=40, \mathrm{Ni}=5, \mathrm{~Pb}=5$ and $\mathrm{Zn}=1$.

The RI classification standard proposed by Hakanson was estimated based on the total toxicity coefficients (133) of As, $\mathrm{Cd}, \mathrm{Cr}, \mathrm{Cu}, \mathrm{Hg}, \mathrm{Pb}, \mathrm{Zn}$ and Polychlorinated biphenyls (PCBs), and the corresponding RI limit was 150 [35]. In this study, PCBs were excluded, and the total toxicity coefficient of the eight heavy metals was 98 . Hence, the ecological risk of heavy metals in stream sediments is likely to be underestimated if the original standard is adopted. Due to the above considerations, we decided to revise the RI grading standard, $R I=150 \times(98 / 133) \approx 110$, and then double it in turn. The individual heavy metals in sediments and the modified RI grade are listed in Table 4.

\subsection{Data Processing}

Excel 2007 and SPSS (20, IBM, New York, NY, USA) were used for data processing and statistical analysis, and the maps were drawn by Arcgis 10.5 and Coreldraw (X4, Corel, Ottawa, ON, Canada). 
Table 4. Ecological risk index and grades of risk intensity. /: null.

\begin{tabular}{cccc}
\hline $\boldsymbol{E}_{\boldsymbol{r}} \boldsymbol{r}$ & Ecological Risk Level & $\boldsymbol{R I}$ & Comprehensive Potential Ecological Risk Level \\
\hline$<40$ & low & $<110$ & low \\
$40-80$ & moderate & $110-220$ & moderate \\
$80-160$ & considerable & $220-440$ & considerable \\
$160-320$ & high & $\geq 440$ & very high \\
$\geq 320$ & Very high & $/$ & $/$ \\
\hline
\end{tabular}

\section{Results and Discussion}

\subsection{The Concentration of Heavy Metals}

The average contents of $\mathrm{As}, \mathrm{Cd}, \mathrm{Cr}, \mathrm{Cu}, \mathrm{Hg}, \mathrm{Ni}, \mathrm{Pb}$ and $\mathrm{Zn}$ are $6.48 \mathrm{ppm}, 0.14 \mathrm{ppm}$, $252.98 \mathrm{ppm}, 339.23 \mathrm{ppm}$ and $0.017 \mathrm{ppm}, 61.98 \mathrm{ppm}, 13.54 \mathrm{ppm}$ and $221.96 \mathrm{ppm}$, respectively (Table 5). Taking the calculated median of elements as their background values, we can conclude that the background values of the above metals were $2.97 \mathrm{ppm}, 0.13 \mathrm{ppm}$, 212.60 ppm, 322.53 ppm, 0.013 ppm, 64.42 ppm, 12.58 ppm and 198.85 ppm, respectively. Compared with the abundance of the continental crust [36,37], the stream sediments in the study area are enriched in $\mathrm{Cu}$, and moderately enriched in $\mathrm{As}, \mathrm{Cd}, \mathrm{Cr}, \mathrm{Ni}$ and $\mathrm{Pb}$, which may be partly inherited from the geochemical characteristics of basalt basement covering the whole region. While relatively depleted in $\mathrm{Hg}$. Among the eight elements, the content of As has the most extensive range and variation coefficient, and its average is higher than the median, indicating that the As may have multiple sources. However, the contents of the remaining elements have small ranges and variation coefficients, and their average is slightly higher than the median or equivalent, indicating that there are fewer outliers with high contents and fewer human sources [38].

Turekian et al. [26] presented a table of abundances of the elements in the various significant units of the earth's lithic crust and gave the global average basalt concentration. Compared with the results of this paper, the $\mathrm{As}, \mathrm{Cr}, \mathrm{Cu}, \mathrm{Pb}$ and $\mathrm{Zn}$ of the global average basalt are lower than those in stream sediments of the Misiones province, while the $\mathrm{Cd}, \mathrm{Hg}$ and $\mathrm{Ni}$ are higher than those of the study area. The risk assessment information system (RAIS), sponsored by the US Department of Energy, provides the latest generic background values of soil on its website (https: / / rais.ornl.gov/, accessed on 12 July 2021) [39], in which the background values of $\mathrm{As}, \mathrm{Cd}, \mathrm{Hg}$ and $\mathrm{Pb}$ are higher than that of the stream sediments obtained in this study. However, $\mathrm{Cr}, \mathrm{Cu}, \mathrm{Ni}$ and $\mathrm{Zn}$ are significantly lower than the results of this study. According to the European Commission Technical Guidance Document, the UK Environmental Protection Agency has developed soil screening values to screen possible ecological risks. If the concentration of pollutants exceeds the screening value, more advanced methods of investigation and evaluation should be carried out to determine whether there are ecological risks $[40,41]$. The background values of $\mathrm{Cr}, \mathrm{Cu}, \mathrm{Ni}$ and $\mathrm{Zn}$ in stream sediments of the study area are significantly higher than the screening value, while As, $\mathrm{Cd}, \mathrm{Hg}$ and $\mathrm{Pb}$ are below the screening value. At the same time, the US environmental protection agency has also developed its ecological soil screening value system, which provides a general screening value of soil pollutant concentrations based on ecological and environmental protection. The background values of $\mathrm{Cr}, \mathrm{Cu}$ and $\mathrm{Zn}$ in stream sediments are significantly higher than the screening values, while the values of $\mathrm{As}, \mathrm{Cd}, \mathrm{Hg}, \mathrm{Ni}$ and $\mathrm{Pb}$ are lower than the screening values. The Canadian Council of Ministers of the Environment issued agricultural soil quality guidelines for environmental and human health protection in 1999 [42], and the guide values of Zn and Ni were updated in 2015 and 2018, respectively. The background values of $\mathrm{Cr}, \mathrm{Cu}$, and $\mathrm{Ni}$ in stream sediments are significantly higher than those guidelines, while $\mathrm{As}, \mathrm{Cd}, \mathrm{Hg}, \mathrm{Pb}$ and $\mathrm{Zn}$ are lower than those guidelines. In conclusion, the $\mathrm{Cr}, \mathrm{Cu}, \mathrm{Ni}$ and $\mathrm{Zn}$ concentrations in the Misiones province stream sediments are higher, which is more likely to cause ecological risks. In contrast, the ecological risks of $\mathrm{As}, \mathrm{Cd}, \mathrm{Hg}$ and $\mathrm{Pb}$ are unlikely in this area. 
Castro et al. [25] gave the concentrations(ppm) of $\mathrm{Cd}, \mathrm{Cr}, \mathrm{Cu}, \mathrm{Ni}, \mathrm{Pb}, \mathrm{Zn}$ in the soils of Buenos Aires province and Córdoba province, respectively, which were 2.25, 46.3, 30.55, $15,20.1,87.33$ and 1.4., 51, 29.7, 15.95, 19.05, 105.25. Compared with the results of this study, the concentrations of $\mathrm{Cr}, \mathrm{Cu}, \mathrm{Ni}$ and $\mathrm{Zn}$ are significantly lower, while that of $\mathrm{Cd}$ and $\mathrm{Pb}$ are higher. Chaparro et al. [43] showed that the concentrations(ppm) of $\mathrm{Pb}, \mathrm{Cu}$, $\mathrm{Zn}, \mathrm{Ni}$ and $\mathrm{Cr}$ in stream sediments around La Plata city of Buenos Aires province were $17.5,11.25,55.5,7.25$ and 5.5, respectively. Except for $\mathrm{Pb}$, the concentrations of other metals are lower than our study results. The provinces of Buenos Aires and Córdoba are located in the most economically developed region of Argentina, with the largest populations and high levels of industrialization. As a result, the concentrations of $\mathrm{Pb}$ and $\mathrm{Cd}$ closely related to human activities are higher than that of Misciones province, which is relatively underdeveloped. The basalts throughout the Misciones province are rich in $\mathrm{Cr}, \mathrm{Cu}, \mathrm{Ni}$, $\mathrm{Zn}$ and other elements. Therefore, it can be considered that the high content of these four metals is a reflection of the geological background, and given this, it has become easy to explain why the concentrations of $\mathrm{Cr}, \mathrm{Cu}, \mathrm{Ni}, \mathrm{Zn}$ in the alluvial plains of central and eastern regions are lower.

Table 5. Statistical characteristics of heavy metals in stream sediments of the Misiones province (ppm).

\begin{tabular}{|c|c|c|c|c|c|c|c|c|c|c|c|c|}
\hline Elements & Range & AV & ME & SD & EC & VC & $\mathbf{a}$ & $\mathbf{b}$ & c & d & e & f \\
\hline As & $0.42-33.77$ & 6.48 & 2.97 & 7.42 & 1.19 & 1.14 & 2.5 & 2 & 7.7 & - & 46 & 12 \\
\hline $\mathrm{Cd}$ & $0.028-0.502$ & 0.14 & 0.13 & 0.06 & 1.62 & 0.4 & 0.08 & 0.22 & 0.73 & 1.15 & 0.36 & 1.4 \\
\hline $\mathrm{Cr}$ & $34.70-696.90$ & 252.98 & 212.60 & 137.92 & 1.57 & 0.55 & 135 & 170 & 55 & 21.1 & $34 / 130$ & 64 \\
\hline $\mathrm{Cu}$ & 20.61-966.85 & 339.23 & 322.53 & 146.79 & 11.95 & 0.43 & 27 & 87 & 24 & 88.4 & 49 & 63 \\
\hline $\mathrm{Hg}$ & $0.007-0.078$ & 0.017 & 0.013 & 0.013 & 0.45 & 0.75 & 0.03 & 0.09 & 0.07 & 0.06 & - & 6.6 \\
\hline $\mathrm{Ni}$ & $4.28-104.79$ & 61.98 & 64.42 & 20.18 & 1.09 & 0.33 & 59 & 130 & 18.5 & 25.1 & 130 & 45 \\
\hline $\mathrm{Pb}$ & 4.06-34.12 & 13.54 & 12.58 & 5.63 & 1.14 & 0.42 & 11 & 6 & 20 & 167.9 & 56 & 70 \\
\hline $\mathrm{Zn}$ & $28.70-583.40$ & 221.96 & 198.85 & 92.34 & 2.76 & 0.42 & 72 & 105 & 58.5 & 90.1 & 79 & 250 \\
\hline
\end{tabular}

Notation: $\mathrm{AV}=$ average; $\mathrm{ME}=$ median; $\mathrm{SD}=$ standard deviation; $\mathrm{EC}=$ enrichment coefficient (median/b); VC = variation coefficient (SD/average); $\mathrm{a}=$ the abundance of continental crust; $\mathrm{b}=$ the concentration of global average basalt; $\mathrm{c}=$ RAIS generic background values of soil; $\mathrm{d}=$ the soil screening values of UK Environmental Protection Agency; $\mathrm{e}=$ the soil screening values of US Environmental Protection Agency; $\mathrm{f}=$ the soil quality guidelines of Canadian Environmental Protection Agency.

\subsection{The Distribution Characteristics of Heavy Metals}

Based on the obtained data on eight heavy metals, we drew their geochemical maps with the 85th percentile as the anomaly threshold (Figure 2). The threshold of As in stream sediments of the Misiones province is $14.29 \mathrm{ppm}$, and its distribution in the whole region is characterized as high in the west and low in the east. The high values are mainly distributed along Iguazu, Eldorado and Rico cities in the west, and around the city of Apostoles in the southwest. These areas have high population densities and relatively intense human activities, which may increase anthropogenic emissions of As and cause anomalies.

The threshold of $\mathrm{Cd}$ is $0.18 \mathrm{ppm}$, and its distribution has no apparent regularity. The high-value areas are mainly distributed in the east and west of Salto city and Bernardo city. In contrast, the low-value areas are concentrated in the north of this area. The threshold of $\mathrm{Cr}$ is $390.53 \mathrm{ppm}$, and its distribution in the whole region showed high values in the north and low values in the south. The high values are concentrated, and distributed mainly along the cities of Rico, Eldorado, and Iguazu, and the northern region. In contrast, the low values are scattered in the central and southern regions, opposite to $\mathrm{Cd}$. The threshold of $\mathrm{Cu}$ is $390.53 \mathrm{ppm}$, and its distribution is related to geological background, weathering and mineralization. The low values are primarily located in the Quaternary calcareous sedimentary areas, mainly distributed along Posadas and Apostoles and South of Iguazu city. In contrast, the high values are concentrated and mainly distributed between the cities of Salto and San Pedro in the central and eastern part of the study area, consistent with the distribution of tholeiites in this area. It can be interpreted that the supergene weathering of basalts and other basic rocks can cause $\mathrm{Cu}$ anomalies. The threshold of $\mathrm{Hg}$ is $0.0237 \mathrm{ppm}$, and its extremal regions are scattered. The high values are primarily distributed in the 
central and eastern parts of the province and the middle of the cities of Posadas and Salto. In contrast, the low-value areas were mainly located in the vicinity of Posadas, Apostoles and Iguazu. The threshold of $\mathrm{Ni}$ is $79.60 \mathrm{ppm}$, and the high and low values were scattered. The high values were distributed in the middle region between Posadas and Salto, while the low values were mainly distributed in the vicinity of Posadas, Apostoles and Iguazu. The threshold of $\mathrm{Pb}$ is $18.93 \mathrm{ppm}$, and its extremal regions are concentrated. The high values are primarily distributed in Posadas and Apostoles cities in the south and Iguazu city in the north. In contrast, the low values mainly occurred in the middle of Eldorado and San Pedro. The threshold of $\mathrm{Zn}$ is $321.85 \mathrm{ppm}$, and its distribution characteristics are similar to $\mathrm{Cu}$, which may be related to mineralization. The high values primarily occurred in the tholeiite area of the study area, while the low values mainly appeared around the Posadas and Apostoles cities in the south.

The concentration of metals in stream sediments mainly depends on the source of parent materials and the influence of human activities in the basin. Concentration correlation analysis of different elements is helpful to understand the spatial variation trends of them, and can reflect the source, existence form and pollution status to a certain extent [44]. The Pearson correlation matrix analysis of heavy-metal contents in stream sediments of the Misiones province is shown in Table 6. The results showed that $\mathrm{Cd}, \mathrm{Cr}, \mathrm{Cu}, \mathrm{Ni}$ and $\mathrm{Zn}$ were significantly positively correlated with each other, with correlation coefficients ranging from 0.320 to 0.890 , implying that these metals may have similar sources. Furthermore, As, $\mathrm{Hg}$ and $\mathrm{Pb}$ were positively correlated with each other, with correlation coefficients ranging from 0.298 to 0.692 , indicating that they may have similar sources.
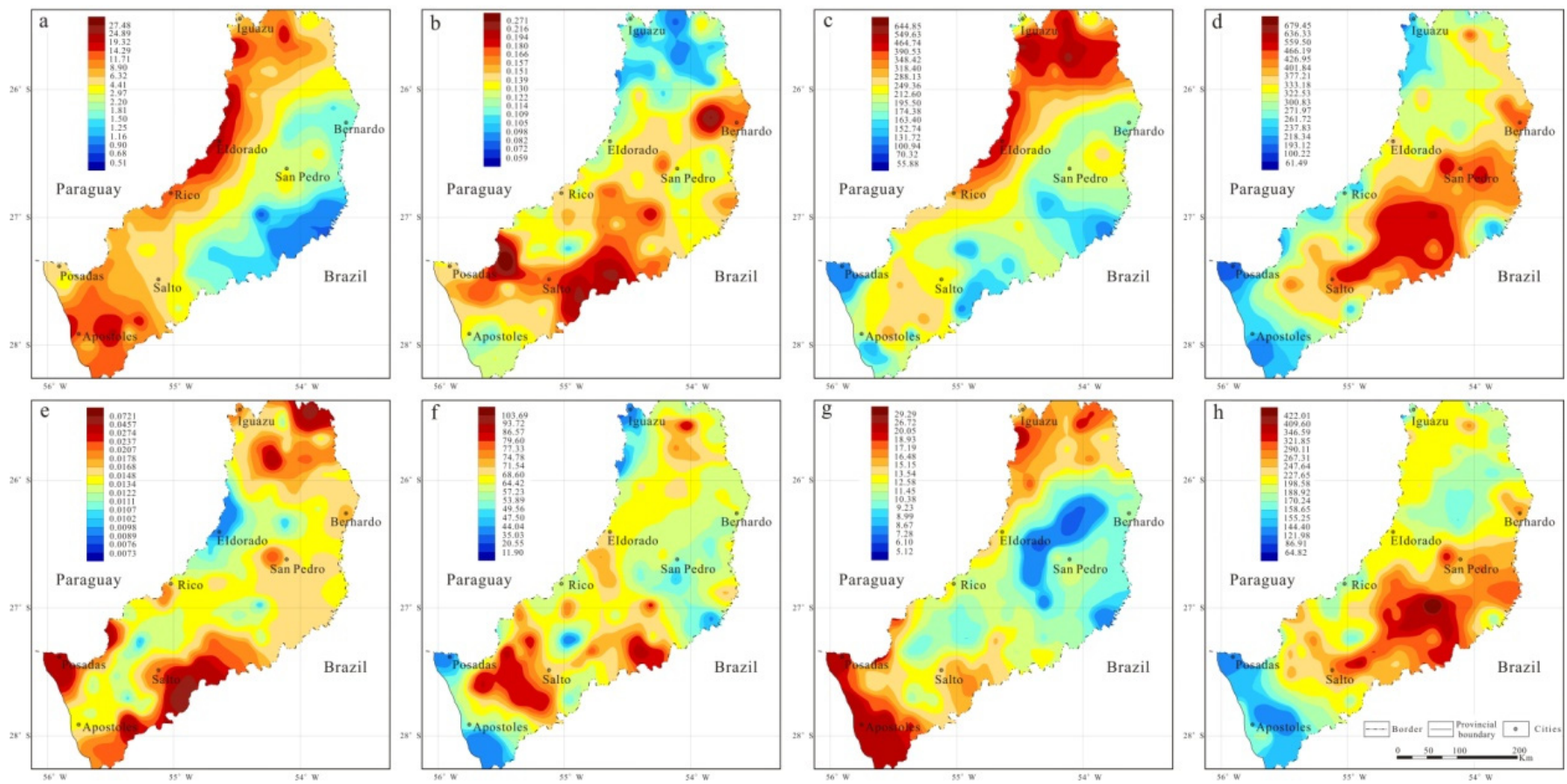

Figure 2. Geochemical maps of $\mathrm{As} \mathrm{(a),} \mathrm{Cd}(\mathbf{b}), \mathrm{Cr}(\mathbf{c}), \mathrm{Cu}(\mathbf{d}), \mathrm{Hg}(\mathbf{e}), \mathrm{Ni}(\mathbf{f}), \mathrm{Pb}(\mathbf{g})$ and $\mathrm{Zn}(\mathbf{h})$.

In order to further analyze the pollution sources of $\mathrm{As}, \mathrm{Cd}, \mathrm{Cr}, \mathrm{Cu}, \mathrm{Hg}, \mathrm{Ni}, \mathrm{Pb}$ and $\mathrm{Zn}$ in stream sediments of the Misciones province, the factor analysis method was used. The results showed that two factors were extracted (Table 7), which could explain $85.16 \%$ of the total variation. The first factor includes $\mathrm{Cd}, \mathrm{Cr}, \mathrm{Cu}, \mathrm{Ni}$ and $\mathrm{Zn}$. He et al. [45] considered that $\mathrm{Cu}-\mathrm{Cr}-\mathrm{Ni}-\mathrm{Zn}$ is a set of probasic rock-element associations, which is widely distributed in the area of basalts and their peripheral pyroclastic rocks. Therefore, we believe that this factor explains the natural source of heavy metals in stream sediments of the study area. 
Table 6. Pearson correlation coefficients between heavy metals in stream sediments.

\begin{tabular}{cccccccc}
\hline Elements & As & $\mathbf{C d}$ & $\mathbf{C r}$ & $\mathbf{C u}$ & $\mathbf{H g}$ & $\mathbf{N i}$ & $\mathbf{P b}$ \\
\hline $\mathrm{As}$ & 1 & & & & & & \\
$\mathrm{Cd}$ & -0.163 & 1 & & & & & \\
$\mathrm{Cr}$ & $-0.256^{* *}$ & $-0.217^{*}$ & 1 & & & & \\
$\mathrm{Cu}$ & $-0.190^{*}$ & $0.350^{* *}$ & 0.047 & 1 & & & \\
$\mathrm{Hg}$ & $0.692^{* *}$ & $0.258^{* *}$ & $-0.322^{* *}$ & -0.154 & 1 & & \\
$\mathrm{Ni}$ & 0.055 & $0.396^{* *}$ & $0.320^{* *}$ & $0.651^{* *}$ & $-0.182^{*}$ & 1 & \\
$\mathrm{~Pb}$ & $0.428^{* *}$ & $0.004^{* *}$ & $0.288^{* *}$ & 0.003 & $0.298^{* *}$ & -0.018 & 1 \\
$\mathrm{Zn}$ & -0.153 & $0.374^{* *}$ & 0.075 & $0.890^{* *}$ & -0.121 & $0.579^{* *}$ & 0.079 \\
\hline
\end{tabular}

Notation: ${ }^{* *}=$ the correlation was significant at the level of 0.01 in bilateral test; ${ }^{*}=$ the correlation was significant at the level of 0.05 in bilateral test; $\mathrm{N}=128$.

Table 7. Rotated matrix of factor analysis (\%).

\begin{tabular}{ccc}
\hline Elements & F1 & F2 \\
\hline $\mathrm{As}$ & -0.13 & 0.90 \\
$\mathrm{Cd}$ & 0.56 & -0.24 \\
$\mathrm{Cr}$ & 0.67 & 0.13 \\
$\mathrm{Cu}$ & 0.92 & -0.06 \\
$\mathrm{Hg}$ & -0.13 & 0.86 \\
$\mathrm{Ni}$ & 0.82 & 0.19 \\
$\mathrm{~Pb}$ & 0.32 & 0.65 \\
$\mathrm{Zn}$ & 0.91 & -0.02
\end{tabular}

Notation: extraction method = principal component analysis; rotation method = orthogonal rotation method with Kaiser standardization.

The second factor includes $\mathrm{As}, \mathrm{Hg}$ and $\mathrm{Pb}$. Wu et al. [46] found that nonferrous metal smelting, coal-burning, and chemical plant production can discharge much $\mathrm{Hg}$ to nature. In addition, improper disposal of household wastes containing $\mathrm{Hg}$, such as batteries and fluorescent lamps, will also cause $\mathrm{Hg}$ pollution in soil [47]. Most of the soil investigated in this study are related to agriculture. Chen et al. [48] pointed out that pesticides would cause the increase of As in agricultural soil. Most areas of the Misiones province are dominated by agricultural land. Meanwhile, Boglione et al. [19] believed that the laterite weathered from basalt in this region has a strong adsorption effect on As. The use of sludge as farmland soil, the application of pesticides and fertilizers, and industrial wastewater and domestic sewage for irrigation can also lead to an increase in the concentration of various heavy metals $[49,50]$. In summary, we conclude that the second factor represents the anthropogenic source of heavy metals. The loading of $\mathrm{Pb}$ in the first factor is 0.32 , indicating that $\mathrm{Pb}$ content also superimposed the influence of parent soil. The concentrations of $\mathrm{As}, \mathrm{Hg}$ and $\mathrm{Pb}$ in Posadas, Apostoles and Iguazu are relatively high, indicating that they may come from human activities.

\subsection{The Pollution and Ecological Risk Assessment of Heavy Metals}

\subsubsection{Igeo}

The average geoaccumulation indices of $\mathrm{As}, \mathrm{Cd}, \mathrm{Cr}, \mathrm{Cu}, \mathrm{Hg}, \mathrm{Ni}, \mathrm{Pb}$ and $\mathrm{Zn}$ in the stream sediments of the Misiones province calculated by the method of $I_{\text {geo }}$ are $0.25(-2.83-3.49),-1.34(-3.56-0.60),-0.22(-2.88-1.45), 1.21(-2.66-2.89),-3.18(-4.34-0.79)$, $-1.78(-5.51--0.90), 0.47(-1.15-1.92)$ and $0.36(-2.46-1.89)$, respectively. According to the classification criteria in Table 2, 94.53\% of sampling points were Cu contaminated, and some sites had been moderately to heavily contaminated. $\mathrm{Pb}, \mathrm{Zn}$, and As were mildly contaminated, and their polluted sites account for $78.91 \%, 78.13 \%$, and $49.22 \%$ of the total. $\mathrm{Cr}$ was uncontaminated except for a few points with mild and moderate contamination. Only two sampling points of $\mathrm{Cd}$ were mildly contaminated, and the rest were pollution-free. All points of $\mathrm{Hg}$ and $\mathrm{Ni}$ were uncontaminated. The order of heavy-metal pollution levels in stream sediments is $\mathrm{Cu}>\mathrm{Pb}>\mathrm{Zn}>\mathrm{As}>\mathrm{Cr}>\mathrm{Cd}>\mathrm{Ni}>\mathrm{Hg}$ (Figure 3), which tell us 
that attention should be paid to the pollution of $\mathrm{Cu}, \mathrm{Pb}$ and $\mathrm{Zn}$ in stream sediments of the Misiones province.

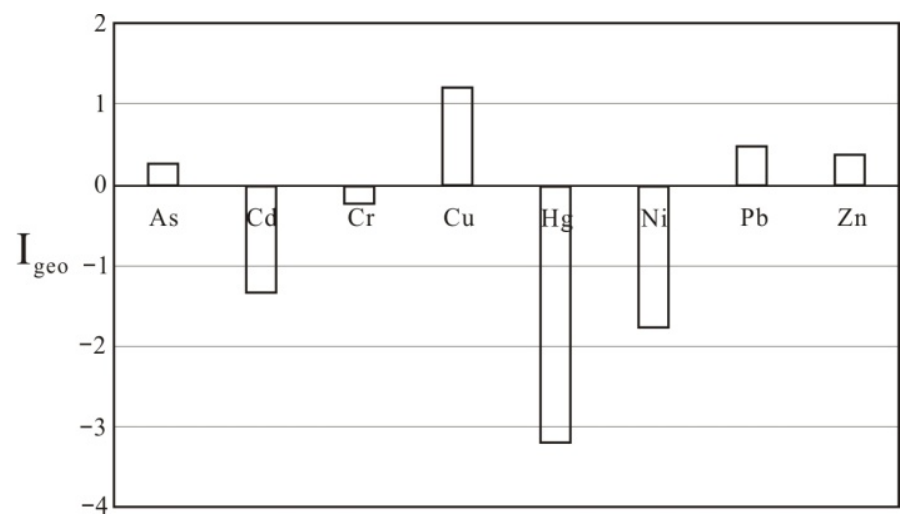

Figure 3. Histogram of the average geoaccumulation indices of heavy metals.

\subsubsection{EF}

As shown from Figure $4, \mathrm{Cu}, \mathrm{Pb}$ and $\mathrm{Zn}$ in the stream sediments of the Misiones province were generally moderately enriched, belonging to the moderate pollution level, with the median of EF being 3.99, 2.38, and 2.12, respectively. Among them, Cu reached moderately severe enrichment at 24 sampling points, while most of the others were moderately enriched. There were six sites of moderately severe $\mathrm{Pb}$ enrichment and 82 sites of moderate $\mathrm{Pb}$ enrichment. Except for one moderately severe enrichment site and 74 moderately enriched sites, all the other sites were pollution-free of $\mathrm{Zn}$. As, $\mathrm{Cr}, \mathrm{Cd}, \mathrm{Ni}$ and $\mathrm{Hg}$ showed no or minor enrichment, belonging to the uncontaminated level, and their median of EF was 1.52, 1.37, 0.64, 0.50 and 0.17, respectively. Among them, all sites of $\mathrm{Ni}$ and $\mathrm{Hg}$ showed no or minor enrichment; $\mathrm{Cd}$ showed no or minor enrichment except for one point with moderately enriched; 13 sites were moderately $\mathrm{Cr}$ enriched, and the rest were pollution-free of $\mathrm{Cr}$. Although As was uncontaminated on the whole, there was severe enrichment at one site, moderately severe enrichment at 32 sites and moderate enrichment at 26 sites, which also needs attention. The assessment results of heavy-metal pollution in stream sediments of the Misiones province by EF is similar to $I_{g e o}$.

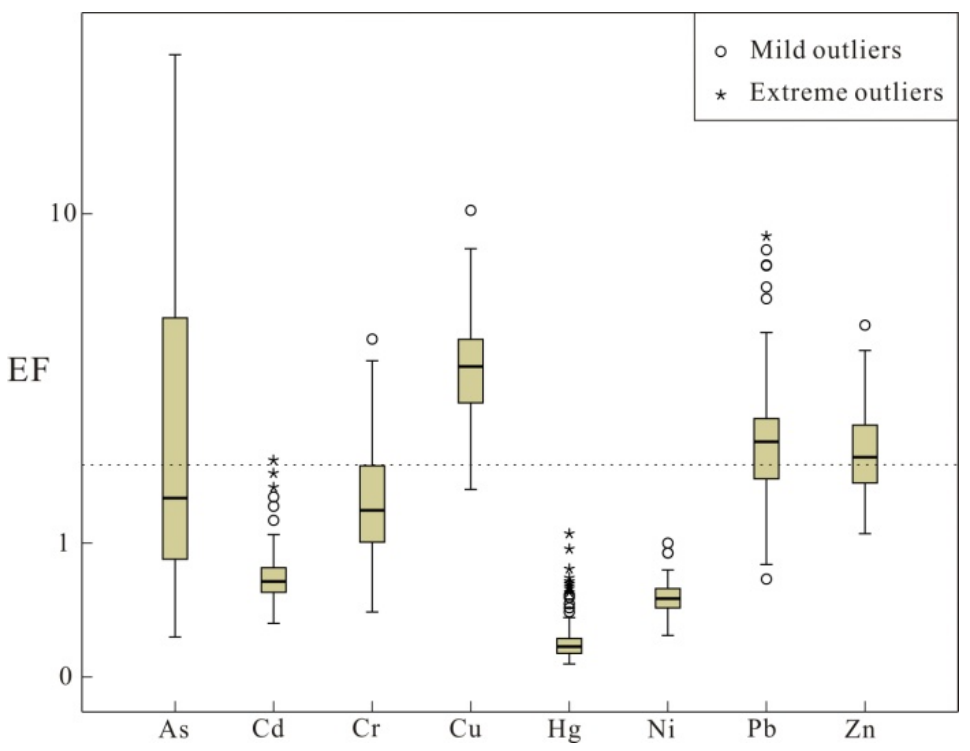

Figure 4. Boxplot for enrichment factors of heavy metals in stream sediments of the Misiones province. 


\subsubsection{PERI}

As shown in Table 7, the $E_{r}^{i}$ of $\mathrm{Cr}, \mathrm{Hg}, \mathrm{Ni}, \mathrm{Pb}$ and $\mathrm{Zn}$ in stream sediments of the Misiones province were lower than 40, indicating a low ecological risk level. $\mathrm{Cd}$ and $\mathrm{Cu}$ showed low ecological risk except for two points of moderate risk. As also presented a low-risk level on the whole, but the sites with $E_{r}^{i}$ greater than 40 account for $26.56 \%$ of the total, among which one point was a severe risk level, 16 points were a moderately severe risk level, and 17 points were a moderate risk level. These points with high ecological risk of As also need attention.

The order of $E_{r}^{i}$ in stream sediments of the study area is $\mathrm{As}>\mathrm{Cu}>\mathrm{Cd}>\mathrm{Pb}>\mathrm{Hg}>\mathrm{Cr}$ $>\mathrm{Ni}>\mathrm{Zn}$, which is generally consistent with the ranking of pollution levels obtained by $I_{\text {geo }}$ and EF. However, due to the different focus on these methods, there are also differences in the ranking of elements. The first two methods can give the pollution level of heavy metals intuitively but do not consider the biological toxicity; the latter reflects the toxicity and relative contribution ratio of heavy-metal pollution to organisms. Therefore, in the actual assessment of heavy-metal pollution levels and potential ecological risk levels, these methods must be effectively combined to comprehensively and scientifically evaluate heavy-metal pollution [34].

Table 8 shows that the $R I$ of heavy metals at 128 sampling points ranges from 18.26 to 240.44 , and the average is 97.35 . Among them, $75 \%$ (96 sites) had low ecological risk $(R I<110), 24.22 \%$ (31 sites) had moderate ecological risk $(110 \leq R I<220)$, and one site had severe ecological risk $(220 \leq R I<440)$. On the whole, the potential ecological risk of heavy metals in stream sediments of the Misiones province is low. However, As and $\mathrm{Cu}$ have the highest contribution rate $(53.32 \%)$ to the $R I$ of heavy metals in the study area, implying that $\mathrm{As}$ and $\mathrm{Cu}$ are the primary pollutants in stream sediments of Misiones province, and individual sampling points have high ecological risk and need attention.

Table 8. PERI results of heavy metals in stream sediments of the Misiones province.

\begin{tabular}{cccccccccc}
\hline \multirow{2}{*}{ Parameters } & $\mathbf{A s}$ & $\mathbf{C d}$ & $\mathbf{C r}$ & $\mathbf{C u}$ & $\mathbf{H g}$ & $\mathbf{N i}$ & $\mathbf{P b}$ & $\mathbf{Z n}$ & $\boldsymbol{R I}$ \\
\hline Max & 168.85 & 68.44 & 8.20 & 55.57 & 34.76 & 4.03 & 28.43 & 5.56 & 240.44 \\
Min & 2.11 & 3.81 & 0.41 & 1.18 & 2.97 & 0.16 & 3.38 & 0.27 & 18.26 \\
AV & 32.41 & 18.95 & 2.98 & 19.50 & 7.74 & 2.38 & 11.28 & 2.11 & 97.35 \\
ROC & $33.29 \%$ & $19.47 \%$ & $3.06 \%$ & $20.03 \%$ & $7.95 \%$ & $2.45 \%$ & $11.59 \%$ & $2.16 \%$ & $100 \%$ \\
\hline
\end{tabular}

Notation: $\mathrm{ROC}=$ rate of contribution.

\section{Conclusions}

We believe that this paper still has shortcomings in heavy-metal fractions and mineralogical composition of stream sediments. In future research, we plan to focus on the study of soil types, heavy-metal forms and mineral composition of stream sediments in this area. Despite the shortcomings, this paper still makes a series of conclusions, listed as follows:

(1) The background values of $\mathrm{As}, \mathrm{Cd}, \mathrm{Cr}, \mathrm{Cu}, \mathrm{Hg}, \mathrm{Ni}, \mathrm{Pb}$ and $\mathrm{Zn}$ in stream sediments of the Misiones province are $2.97 \mathrm{ppm}, 0.13 \mathrm{ppm}, 212.60 \mathrm{ppm}, 322.53 \mathrm{ppm}, 0.013 \mathrm{ppm}$, $64.42 \mathrm{ppm}, 12.58 \mathrm{ppm}$ and $198.85 \mathrm{ppm}$, respectively. Compared with the abundance of continental crust, $\mathrm{Cu}$ is significantly enriched, $\mathrm{Zn}, \mathrm{As}, \mathrm{Cd}, \mathrm{Cr}, \mathrm{Ni}$ and $\mathrm{Pb}$ are moderately enriched, while $\mathrm{Hg}$ is relatively depleted.

(2) Except for $\mathrm{Cu}$ and $\mathrm{Zn}$, the distribution characteristics of these heavy metals are different. Factor analysis showed that $\mathrm{Cd}, \mathrm{Cr}, \mathrm{Cu}, \mathrm{Ni}$ and $\mathrm{Zn}$ in stream sediments of the Misiones province were primarily controlled by geological background and belong to natural sources; As and Hg represent anthropogenic sources, and their concentrations were affected by human activities. $\mathrm{Pb}$ was not only controlled by geological background but was also related to human activities.

(3) The pollution evaluation results obtained by the geoaccumulation index and enrichment factor are similar. Both showed moderately severe $\mathrm{Cu}$ contamination in the 
stream sediments of the study area, $\mathrm{Pb}$ and $\mathrm{Zn}$ were of mild contamination, and most of As, $\mathrm{Cr}, \mathrm{Cd}, \mathrm{Ni}$ and $\mathrm{Hg}$ were at uncontaminated levels.

(4) The order of potential ecological risk index of heavy metals was $\mathrm{As}>\mathrm{Cu}>\mathrm{Cd}>\mathrm{Pb}$ $>\mathrm{Hg}>\mathrm{Cr}>\mathrm{Ni}>\mathrm{Zn}$. The comprehensive potential ecological-risk index indicated that the potential ecological risk of heavy metals in the Misiones province was low. However, the sum of the As and Cu ecological risk indices accounted for $53.32 \%$ of the total, implying that these two metals have the highest potential ecological risk in stream sediments. Therefore, attention should be paid to the ecological risks of $\mathrm{As}$ and $\mathrm{Cu}$ in stream sediments of the Misiones province.

Author Contributions: Conceptualization, D.Z. and Y.C.; methodology, D.Z.; software, D.Z.; validation, Y.C., X.C. (Xi-feng Chen) and F.Z.; formal analysis, D.Z.; investigation, X.C. (Xifeng Chen); resources, X.C. (Xiufa Chen); data curation, Y.C.; writing-original draft preparation, D.Z.; writingreview and editing, D.Z.; visualization, D.Z.; supervision, Y.C.; project administration, W.Z.; funding acquisi-tion, W.Z. All authors have read and agreed to the published version of the manuscript.

Funding: This research was funded by the geological survey project of The China Geological Survey (No. DD202111404).

Conflicts of Interest: The authors declare no conflict of interest.

\section{References}

1. Zhu, Q.Q.; Wang, Z.L. Distribution characteristics and source analysis of heavy metals in sediments of the main river systems in China. Earth Environ. 2012, 40, 305-313.

2. Horowitz, A.J.; Rlrick, K.A. The relation of stream sediment surface area, grain size and composition to trace element chemistry. Appl. Geochem. 1987, 2, 437-451. [CrossRef]

3. Xie, X.J.; Zhou, G.H. Multi-purpose regional geochemical mapping and multi-level environmental geochemistry monitoring network: Its basic concept and methodology. Geol. Bull. China 2002, 21, 809-816.

4. Simex, S.A.; Helz, G.R. Regional geochemistry of trace elements in Checapeake Bay. Environ. Geol. 1981, 3, 315-323. [CrossRef]

5. Grunsky, E.C.; Drew, L.J.; Sutphin, D.M. Process recognition in multi-element soil and stream-sediment geochemical data. Appl. Geochem. 2009, 24, 1602-1616. [CrossRef]

6. Albanese, S.; Taiani, M.V.E.; De Vivo, B.; Lima, A. An environmental epidemiological study based on the stream sediment geochemistry of the Salerno province (Campania region, Southern Italy). J. Geochem. Explor. 2013, 131, 59-66. [CrossRef]

7. Horasan, B.Y.; Arik, F. Assessing heavy metal pollution in the surface soils of central anatolia region of Turkey. Carpath. J. Earth Environ. Sci. 2019, 14, 107-118. [CrossRef]

8. Xie, X.J.; Cheng, H.X. The suitability of floodplain sediment as a global sampling medium: Evidence from China. J. Geochem. Explor. 1997, 58, 51-62. [CrossRef]

9. Wang, L.; Wang, Y.P.; Xu, C.X.; An, Z.Y. Pollution characteristics and ecological risk assessment of heavy metals in the surface sediments of the Yangtze River, China. Environ. Sci. 2012, 33, 2599-2606.

10. Zheng, J.P.; Jiao, X.M.; Fang, N.J.; Wang, C.Y.; Yuang, G.W.; Lv, Y.; Zhou, C.F. Sources and risk assessment of heavy metals in sediments in Jiangsu coastal areas, China. China Environ. Sci. 2017, 37, 1514-1522.

11. Bilali, L.E.; Rasmussen, P.E.; Hall, G.E.M. Role of sediment composition in trace metal distribution in lake sediments. Appl. Geochem. 2002, 17, 1171-1181. [CrossRef]

12. Lin, Q.; Liu, E.F.; Zhang, E.L.; Li, K.; Shen, J. Spatial distribution, contaminationand ecological risk assessment of heavy metals in surface sediments of Erhai Lake, a large eutrophic plateau lake in southwest China. CATENA 2016, 145, 193-203. [CrossRef]

13. Alain, L.; Raphal, B.; Alain, D.; Axel, T.; Virginie, C.H. Phthalate pollution in an Amazonian rainforest. Environ. Sci. Pollut. Res. 2016, 16, 16865-16872.

14. Rämö, O.T.; Heikkilä, P.A.; Pulkkinen, A.H. Geochemistry of Paraná-Etendeka basalts from Misiones, Argentina: Some new insights into the petrogenesis of high-Ti continental flood basalts. J. S. Am. Earth Sci. 2016, 67, 25-39. [CrossRef]

15. Chen, Y.M.; Zhang, C.; Chen, X.F.; Chen, X.F.; Zhao, H.J. South America Geological Minerals and Mining Development; China University of Geosciences Press: Wuhan, China, 2018; pp. 1-48.

16. Lavado, R.S.; Rodriguez, M.B.; Scheiner, J.D.; Taboada, M.A.; Rubio, G.; Alvarez, R.; Alconada, M.; Zubillaga, M.S. Toxic metals in soils of Argentina: Comparison between urban and agricultural soils. Commun. Soil Sci. Plant Anal. 1998, 29, 1913-1917. [CrossRef]

17. Lavado, R.S.; Zubillaga, M.S.; Álvarez, R.; Taboada, M.A. Baseline levels of potentially toxic elements in Pampas soils. Soil Sed. Contam. 2004, 13, 329-339. [CrossRef]

18. Cittadino, A.; Ocello, N.; Majul, M.V.; Ajhuacho, R.; Dietrich, P.; Igarzabal, M.A. Heavy metal pollution and health risk assessment of soils from open dumps in the Metropolitan Area of Buenos Aires, Argentina. Environ. Monit. Assess. 2020, 192, 291. [CrossRef] 
19. Boglione, R.; Griffa, C.; Panigatti, M.C.; Keller, S.; Schierano, C.M.; Asforno, M. Arsenic adsorption by soil from Misiones province, Argentina. Environ. Technol. Innov. 2019, 13, 30-36. [CrossRef]

20. Wang, X.Q.; Chi, Q.H.; Liu, H.Y.; Nie, L.S.; Zhang, B.M. Wide-spaced sampling for delineation of geochemical provinces in desert terrains, northwestern China. Geochem. Explor. Environ. Anal. 2007, 2, 153-161. [CrossRef]

21. Wang, X.Q.; Xu, S.F.; Zhang, B.M.; Zhao, S.D. Deep-penetrating geochemistry for sandstone-type uranium deposits in the Turpan-Hami basin, north-western China. Appl. Geochem. 2011, 12, 2238-2246. [CrossRef]

22. Wang, X.Q.; Zhang, B.M.; Lin, X.; Xu, S.F.; Yao, W.S.; Ye, R. Geochemical challenges of diverse regolith-covered terrains for mineral exploration in China. Ore. Geol. Rev. 2016, 73, 417-431.

23. Tian, M.; Wang, X.Q.; Nie, L.S.; Liu, H.L.; Wang, W.; Yan, T.T. Spatial distributions and the identifification of ore-related anomalies of $\mathrm{Cu}$ across the boundary area of China and Mongolia. J. Geochem. Explor. 2019, 197, 37-47. [CrossRef]

24. Müller, G. Index of geoaccumulation in sediments of the Rhine River. Geojournal 1969, 2, 108-118.

25. Castro, L.N.; Rendina, A.E.; Orgeira, M.J. Assessment of toxic metal contamination using a regional lithogenic geochemical background, Pampean area river basin, Argentina. Sci. Total Environ. 2018, 627, 125-133. [CrossRef]

26. Turekian, K.K.; Wedepohl, K.H. Distribution of the elements in some major units of the earth's crust. Geol. Soc. Am. 1961, 72, 175-192. [CrossRef]

27. Magni, L.F.; Castro, L.N.; Rendina, A.E. Evaluation of heavy metal contamination levels in river sediments and their risk to human health in urban areas: A case study in the Matanza-Riachuelo Basin, Argentina. Environ. Res. 2021, 197, 110979. [CrossRef] [PubMed]

28. Abrahim, G.M.S.; Parker, R.J. Assessment of toxic metal enrichment factors and the degree of contamination in marine sediments from Tamaki Estuary, Auckland, New Zealand. Environ. Monit. Assess. 2008, 136, 227-238. [CrossRef]

29. Nowrouzi, M.; Pourkhabbaz, A. Application of geoaccumulation index and enrichment factor for assessing metal contamination in the sediments of Hara Biosphere Reserve, Iran. Chem. Speciat. Bioavailab. 2014, 26, 99-105. [CrossRef]

30. Williams, J.A.; Antoine, J. Evaluation of the elemental pollution status of Jamaican surface sediments using enrichment factor, geoaccumulation index, ecological risk and potential ecological risk index. Marine Pollut. Bull. 2020, 157, 111288. [CrossRef]

31. Zhang, H.H.; Chen, J.J.; Zhu, L.; Yang, G.; Li, D. Anthropogenic mercury enrichment factors and contributions in soils of Guangdong Province, South China. J. Geochem. Explor. 2014, 144, 312-319. [CrossRef]

32. Barbier, M. The importance of enrichment factor $(\mathrm{EF})$ and Geoaccumulation index ( $\left.\mathrm{I}_{\text {geo }}\right)$ to evaluate the soil contamination. J. Geol. Geophys. 2016, 5, 1-4. [CrossRef]

33. Hakanson, L. An ecological risk index for aquatic pollution control: A sedimentological approach. Water Res. 1980, 14, 975-1001. [CrossRef]

34. Saraee, K.R.E.; Abdi, M.R.; Naghavi, K.; Saion, E.; Shafaei, M.A.; Soltani, N. Distribution of heavy metals in surface sediments from the South China Sea ecosystem, Malaysia. Environ. Monit. Assess. 2011, 183, 545-554. [CrossRef]

35. Coskun, A.; Horasan, B.Y.; Ozturk, A. Heavy metal distribution in stream sediments and potential ecological risk assessment in Konya Northeast region. Environ. Earth Sci. 2021, 80, 181. [CrossRef]

36. Wedepohl, K.H. The composition of the continental crust. Geochim. Cosmochim. Acta 1995, 59, 1217-1232. [CrossRef]

37. Rudnick, R.L.; Gao, S. The Composition of the continental crust. In The Crust. Treatise on Geochemistry; Holland, H.D., Turekian, K.K., Eds.; Elsevier-Pergamon: Oxford, UK, 2003; Volume 2, pp. 1-64.

38. Wang, X.S.; Qin, Y. Application of lognormal distribution plot to interpreting sources and determining geochemical background levels of heavy metals in Xuzhou urban soils, Jiangsu province. Geochimica 2007, 36, 98-102.

39. RAIS (The Risk Assessment Information System). Toxicity Values. 2021. Available online: https:/ / rais.ornl.gov/tutorials/toxvals. html\#2.4\%20Derivation\%20of\%20Inhalation\%20RfDs\%20and\%20Slope\%20Factors (accessed on 12 July 2021).

40. Environment Agency. Soil Screening Values for Use in UK Ecological Risk Assessment; Technical Report P5- 091/TR1; Environment Agency: Bristol, UK, 2004.

41. Zheng, L.P.; Wang, G.Q.; Long, T.; Lin, Y.S.; Feng, Y.H.; Zhang, Y.; Zhao, X. A study of risk-based ecological soil screening levels among different countries and its implication for China. Asian J. Ecotoxicol. 2018, 13, 39-49.

42. Canadian Council of Ministers of the Environment. Canadian Soil Quality Guidelines for the Protection of Environmental and Human Health: Polychlorinated Biphenyls (Total). Canadian Environmental Quality Guidelines; Canadian Council of Ministers of the Environment: Winnipeg, MB, Canada, 1999.

43. Chaparro, M.A.E.; Bidegain, J.C.; Sinito, A.M.; Jurado, S.S.; Gogorza, C.S.G. Magnetic studies applied to different environments (soils and stream sediments) from a relatively polluted area in Buenos Aires Province, Argentina. Environ. Geol. 2004, 45, 645-664. [CrossRef]

44. Borg, H.; Jonsson, P. Large-scale metal distribution in Baltic Sea sediments. Marine Pollut. Bull. 1996, 32, 8-21. [CrossRef]

45. He, S.L.; Cheng, G.F.; Liu, Y.Z.; Chen, Z.; Hou, C.L.; Mou, J.; Luo, X.M. Resource potential and prospecting methods of gold geochemical blocks in southwestern Guizhou, China. Acta Mineral. Sinica 2007, 27, 477-482.

46. Wu, Y.; Wang, S.X.; Streets, D.G.; Hao, J.M.; Chan, M.; Jiang, J.K. Trends in anthropogenic mercury emissions in China from 1995 to 2003. Environ. Sci. Technol. 2006, 40, 5312-5318. [CrossRef] [PubMed]

47. Wang, S.L.; Wu, W. Research progress on soil mercury pollution ecology in Guizhou, China. Innov. Appl. Sci. Technol. 2015, 27, 173.

48. Chen, T.B.; Hang, M.H.; Hang, H.Z.; Zhou, H.Y. A study on heavy metal pollution in soils in Hongkong. Acta Geogr. Sinica 1997, 52, 228-236. 
49. Zakir, H.M.; Shikazono, N.; Otomo, K. Geochemical distribution of trace metals and assessment of anthropogenic pollution in sediments of Old Nakagawa River, Tokyo, Japan. Am. J. Environ. Sci. 2008, 4, 654. [CrossRef]

50. Michalak, I.; Saeid, A.; Chojnacka, K.; Gramza, M. Trace elements as fertilizer micronutrients. In Recent Advances in Trace Elements; Chojnacka, K., Saeid, A., Eds.; Wiley-Blackwell: Oxford, UK, 2018; pp. 299-318. 